\title{
Framing fracking: which frames are heard in English planning and environmental policy and practice?
}

Article

Accepted Version

Hilson, C. (2015) Framing fracking: which frames are heard in English planning and environmental policy and practice? Journal of Environmental Law, 27 (2). pp. 177-202. ISSN 1464-374X doi: https://doi.org/10.1093/jel/equ036 Available at https://centaur.reading.ac.uk/38632/

It is advisable to refer to the publisher's version if you intend to cite from the work. See Guidance on citing.

To link to this article DOI: http://dx.doi.org/10.1093/jel/equ036

Publisher: Oxford University Press

All outputs in CentAUR are protected by Intellectual Property Rights law, including copyright law. Copyright and IPR is retained by the creators or other copyright holders. Terms and conditions for use of this material are defined in the End User Agreement.

$\underline{\text { www.reading.ac.uk/centaur }}$

\section{CentAUR}


Central Archive at the University of Reading

Reading's research outputs online 
Framing Fracking: Which Frames are Heard in English Planning and Environmental Policy and Practice?

\author{
Chris Hilson* \\ Professor, School of Law, University of Reading \\ *Email: c.j.hilson@reading.ac.uk.
}

\begin{abstract}
Fracking in England has been the subject of significant controversy and has sparked not only public protest but also an associated framing war with differing social constructions of the technology adopted by different sides. This article explores the frames and counter-frames which have been employed by both the antifracking movement and by government and the oil and gas industry. It then considers the way in which the English planning and regulatory permitting systems have provided space for these frames within the relevant machinery for public participation. The article thus enables one to see which frames have been allowed a voice and which have been excluded.
\end{abstract}

Keywords: Framing , Fracking , Oil and gas , Participation , Planning , Environmental permitting

\title{
Introduction
}

Fracking, or 'hydraulic fracturing' is a technique used in the oil and gas industry to gain access to deposits which are otherwise difficult or impossible to exploit using conventional drilling methods. While it is a technique that has been used globally by the industry over a number of years, both offshore and onshore, it is only in the last couple of years that it has attracted significant headlines and controversy in the United Kingdom (UK). This attention has arisen because, backed by the UK Government, the oil and gas industry has signalled its intention to exploit the UK's newly assessed and apparently substantial onshore shale gas resources. This follows the lead of the United States (US) where, in recent years, a sizeable shale industry has grown up and produced, inter alia, significant reductions in US energy prices. There are always two sides to a controversy however, and while one side looks enviously across the Atlantic at the benefits of the US experience with shale, local communities and environmental groups have pointed towards the environmental and climate change downsides associated with it. The US documentary Gasland, which showed flames coming from people's kitchen taps in Colorado, supposedly as a result of fracking for shale, has become particularly emblematic in this respect. The relative scale of the onshore industry needed to exploit fully the UK's shale resources has also fed the controversy, as has its likely location: on a relatively small island, the large number of well pads needed would represent a step change from the UK's previous small and largely unnoticed onshore operations; and the licence areas lie not just in the industrial North of England, but also in the leafy shires of the South, where vocal middle class opposition has been particularly strong. ${ }^{1}$

\footnotetext{
${ }^{1}$ Prompting a senior Conservative Peer to argue, controversially, in the House of Lords that fracking should be confined to the 'desolate' North East of England: Nigel Morris, 'Former Energy Minister Lord Howell (George Osborne's father-in-law) Says It's Fine to Frack in 'Empty, Desolate' North-east', The Independent, 30 July 2013, < http://www.independent.co.uk/news/uk/politics/former-energy-minister-lord-howell-george-osbornesfatherinlaw-says-its-fine-to-frack-in-empty-desolate-northeast-8738634.html> accessed 28 Nov 2014.
} 
The level and nature of the regulation of the drilling operations associated with fracking has also been a thorny issue. US regulation was very much hands-off, with exemptions made from some key environmental laws to free up the industry. ${ }^{2}$ Critics of course claim that this regulatory laxity stored up pollution problems which have since inevitably begun to reveal themselves - as evidenced by some of the experiences in Gasland and a significant number of lawsuits. ${ }^{3}$ The UK Government has been at pains to emphasise, in contrast, the stringent nature of the UK regulatory controls, while at the same time arguing against the need for specialist regulation of the area. ${ }^{4}$ Environmental groups have typically pressed for a regulatory ban on fracking but failing that or a moratorium, for a more fit for purpose dedicated regime; ${ }^{5}$ they have also pointed out the gaps ${ }^{6}$ or inadequacies ${ }^{7}$ in the existing framework and the catch-up nature of the regulatory response. ${ }^{8}$

Like most policy controversies, fracking has found itself the subject of an intense 'framing' debate. The anti-fracking movement has employed a range of frames as part of its campaigning against the use of fracking in shale gas exploration and development and the oil and gas industry and the Government have asserted their own counter-frames. Framing involves the social construction and communication of reality and is inevitably partial. Just like a picture frame or camera lens, framing is about how people see

2 eg from the Safe Drinking Water Act - see <http://water.epa.gov/type/groundwater/uic/class2/hydraulicfracturing/wells hydroreg.cfm>accessed $28 \mathrm{Nov}$ 2014.

${ }^{3}$ For a catalogue of the numerous US lawsuits, see Barclay Nicholson, 'Analysis of Litigation Involving Shale \& Hydraulic Fracturing' (Norton Rose Fulbright, June 1, 2014), <http://www.nortonrosefulbright.com/files/20140101-analysis-of-litigation-involving-shale-hydraulic-fracturing104256.pdf $>$ accessed 28 Nov 2014.

${ }^{4}$ See eg Department of Energy and Climate Change (DECC), 'About Shale Gas and Hydraulic Fracturing (Fracking)' (30 July 2013) 6-7,

<https://www.gov.uk/government/uploads/system/uploads/attachment_data/file/268017/About shale gas and hydraulic fracturing Dec 2013.pdf> accessed 28 Nov 2014: 'The Government takes the safety of the public and protection of the environment very seriously. We commissioned the Royal Society to review the scientific and engineering evidence on shale gas extraction conducted by the Royal Academy of Engineering and the Royal Society. This concluded that "the health, safety and environmental risks associated with hydraulic fracturing (often termed 'fracking') as a means to extract shale gas can be managed effectively in the UK as long as operational best practices are implemented and enforced through regulation." The Government believes that the regulation is robust for exploration, but wants to continue to improve it.'

${ }^{5}$ See eg Friends of the Earth (FoE), 'All That Glitters ... Is the Regulation of Unconventional Gas and Oil Exploration in England Really 'Gold Standard'? (June 2014) 6, <http://www.foe.co.uk/sites/default/files/downloads/all-glitterscritique-fracking-regulation-46660.pdf> accessed 28 Nov 2014.

${ }^{6}$ See eg Friends of the Earth Scotland (FoES) Hearing Statement in Planning Permission Appeal PPA-240-2032 (Letham Moss) <http://www.foe-

scotland.org.uk/sites/files/FoES\%20Hearing\%20Statement\%20to\%20DPEA\%20re\%20PPA-240-2032\%20FINAL.pdf> accessed 28 Nov 2014). A number of the regulatory gaps in Scotland identified in this FoES submission were subsequently acknowledged in the report commissioned by the Scottish Government: Scottish Government 'Independent Expert Scientific Panel Report on Unconventional Oil And Gas' (July 2014) 6061,<http://www.scotland.gov.uk/Resource/0045/00456579.pdf> accessed 28 Nov 2014>.

${ }^{7}$ See eg FoE (n 5).

${ }^{8}$ eg FoE brought the need for mining waste and radioactive substance permits to the attention of the Environment Agency in relation to Caudrilla's Balcombe site - see FoE press release, 17 June 2013, <http://www.foe.co.uk/resource/press releases/shale cuadrilla must apply for waste permits 17062013> accessed 28 Nov 2014. 
and represent an issue like fracking; like a frame or lens, it is also a strategic choice about which aspects of an issue to focus on and which to exclude. One side's excluded material will often be the other side's focus. As Entman observes, frames will also typically 'diagnose, evaluate and prescribe', with diagnosis identifying the issue or problem and its causes, evaluation making moral judgements, and prescription suggesting remedies or solutions. ${ }^{9}$

From an environmental law perspective, it is interesting to see the extent to which space is allowed for different fracking frames to be aired and considered in decision-making by English public authorities on planning permission and environmental permitting. Do the planning and environmental permitting regimes recognise and legitimate certain types of framing in relation to fracking and not others? Are government frames necessarily privileged, as one might perhaps expect given that government controls the appropriate policy levers? If, as suggested above, framing is about how an issue is seen and what aspects of that issue are focused on, then it worth exploring whether the environmental law mechanisms for public participation in relation to fracking embrace all perspectives and selections or whether they act as a more selective gatekeeper, allowing consideration of some frames and not others. These are questions which this article addresses.

\section{Fracking}

Hydraulic fracturing or fracking involves the drilling of vertical and then horizontal wells followed by the injection of significant quantities of water and smaller amounts of chemicals into the rock in order to release gas which is then extracted. Although fracking is a technique that can in principle be used on various types of rocks, in practice it has mainly been used on shale. Shale gas is an example of 'unconventional' gas along with other types such as coal bed methane and underground coal gasification; they are so-called not because of the unconventional techniques used (such as fracking) or the composition of the gas, ${ }^{10}$ but because of the hard to reach nature of the geological formations in which they are found. 'Conventional' gas, in contrast is extracted from easier to reach, typically shallower rocks. ${ }^{11}$

Although fracking for shale gas has been widely used in the US for a number of years now as part of what is sometimes referred to as its 'shale revolution', its application in Europe has thus far been limited. A number of European states including France ${ }^{12}$ and Germany ${ }^{13}$ have placed either bans or

\footnotetext{
${ }^{9}$ Robert Entman, 'Framing: Towards Clarification of a Fractured Paradigm' (1993) $43 \mathrm{~J}$ of Communication 51, 52.

${ }^{10}$ In fact shale gas, coal bed methane and conventional gas share more in common in compositional terms than the gas produced via underground coal gasification: see Environment Agency, 'What is Unconventional Gas?', <http://webarchive.nationalarchives.gov.uk/20140328084622/http://www.environmentagency.gov.uk/business/topics/126689.aspx> accessed 28 Nov 2014.

${ }^{\frac{1}{11} \text { ibid. }}$

${ }^{12}$ See the Conseil Constitutionnel, Decision no. 2013-346 QPC of 11 October 2013, Schuepbach Energy LLC, upholding as constitutional arts 1 and 3 of Law no. 2011-835 of 13 July 2011 on the prevention of the exploration
} 
moratoria on shale gas exploration and others remain only at the start of the process, with exploration wells either planned or in progress but, as yet, with no proven fields at production stage. ${ }^{14}$ In the UK, fracking was carried out by the company Caudrilla at Preese Hall in Lancashire in 2011, but operations were halted when an earthquake occurred in the local area and a temporary government moratorium was placed on further use of fracking until December 2013. ${ }^{15}$ However fracking really only attracted significant media and public attention in the summer of 2013 when Caudrilla's plans to drill at Balcombe in West Sussex led to mass protests at the proposed drill site. Perhaps ironically given that the application was to use conventional techniques rather than fracking, but because of Caudrilla's association with fracking and a fear that fracking might subsequently be used on the site, Balcombe lit the touch paper for the anti-fracking movement.

The UK regulation of fracking is overseen by The Office of Unconventional Gas and Oil (OUGO) which sits within the Department of Energy and Climate Change's (DECC) Energy Development Unit - the Unit responsible for promoting and overseeing energy development in the UK. ${ }^{16}$ The overall regulatory structure is a complex one. An operator who wishes to drill first requires a Petroleum Exploration and Development Licence (PEDL) from DECC under powers, reserved to Westminster, ${ }^{17}$ in the Petroleum Act $1998 .{ }^{18}$ Under the detailed terms of a licence, set out in 'model clauses', operators must seek prior consent from DECC before a well is drilled. ${ }^{19}$ Operators intending to use fracking are also required, under the licence, to have an outline hydraulic fracture plan reviewed and approved by DECC. ${ }^{20}$ In addition, drilling operations will amount to 'development' under planning law ${ }^{21}$ and will therefore require planning permission. Appropriate permits from the relevant environment agencies within the UK

and exploitation of liquid or gas hydrocarbon mines by hydraulic fracking and revoking exclusive licences to prospect for projects that use this technique with the rights and freedoms guaranteed by the Constitution.

${ }^{13}$ Germany's current moratorium is based only on guidelines and the Federal Environment Agency, the UBA, has been pressing for these to be transposed into law - see the UBA press release No. 33/, 'Regulate Fracking Now', 30 July 2014; and EurActiv, 'Germany Moves Closer to Fracking Ban', 31 July 2014,

<http://www.euractiv.com/sections/energy/germany-moves-closer-fracking-ban-303808> accessed 28 Nov 2014.

${ }^{14}$ Richard Anderson, 'Shale Industry Faces Global Reality Check', BBC News, 7 April 2014,

<http://www.bbc.co.uk/news/business-26735000> accessed 28 Nov 2014; Marek Strzelecki and Brian Swint,

'Europe Nears First Commercial Shale Gas Production in Poland', Bloomberg News, 23 January 2014,

<http://www.bloomberg.com/news/2014-01-23/europe-nears-first-commercial-shale-gas-production-in-poland-1.html $>$ accessed 28 Nov 2014.

${ }^{15}$ DECC, 'Written Ministerial Statement by Edward Davey: Exploration for Shale Gas' (13 December 2012)<https://www.gov.uk/government/speeches/written-ministerial-statement-by-edward-davey-explorationfor-shale-gas> accessed 28 Nov 2014.

${ }^{16}$ This dual role has been identified by some as a potential conflict of interest - see eg Energy and Climate Change Committee, The Impact of Shale Gas on Energy Markets (HC 2012-13, 785-I) para 43.

${ }^{17}$ Under the Scotland Act 1998, Sch 5 Pt 2 Section D2(a).

${ }^{18}$ Ss 3-4.

${ }^{19}$ The Petroleum Licensing (Exploration and Production) (Landward Areas) Regulations 2014, SI 2014/1686, Sch 2, para 20.

${ }^{20}$ See the so-called 'Regulatory Roadmap' - DECC, 'Onshore Oil and Gas Exploration in the UK: Regulation and Best Practice (England) (December 2013) <https://www.gov.uk/government/publications/regulatory-roadmaponshore-oil-and-gas-exploration-in-the-uk-regulation-and-best-practice > accessed 28 Nov 2014.

${ }^{21}$ In England s 55 of The Town and Country Planning Act 1990 and in Scotland s 26(1) of The Town and Country Planning (Scotland) Act 1997. 
will also be required, and well integrity and associated health and safety is controlled via the Health and Safety Executive. ${ }^{22}$ Other permissions may also be required - notably from underground landowners whose land lateral wells (which can extend for up to two miles) ${ }^{23}$ cross. However, although the current law does provide a way of overriding landowner objections on access (to go ahead without permission or such override rights amounts to trespass), the relevant procedures involve considerable delay. For that reason, the Government intends to provide a statutory right of access for drilling operations below 300 metres. $^{24}$

\section{Framing}

Fracking is a classic example of what Schön and Rein describe as an 'intractable policy controversy' which, unlike a policy 'disagreement', is incapable of being settled by references to facts and evidence alone. ${ }^{25}$ In a controversy, different parties are likely to focus attention on different facts and, even when the same facts are under consideration, they tend to interpret them in different ways. ${ }^{26}$ According to Schön and Rein, this interpretative element, or framing, involves 'symbolic contests over the social meaning of an issue domain, where meaning implies not only what is at issue but also what is to be done. ${ }^{27}$ Framing, in other words, involves the social construction of reality. Fracking is not just something 'out there' as a pre-ordained bundle of neutral facts on the ground: it is, rather, an issue which invites interpretation - and such interpretation is likely to differ substantially depending on the interests of those involved. ${ }^{28}$

Although related, frames and arguments should not be conflated. ${ }^{29}$ According to Hänggli and Kriesi:

Frames and arguments are not entirely the same. Framing is the process by which political actors define the issue for their audience ... A frame highlights some aspects of a perceived

\footnotetext{
${ }^{22}$ The generic framework for health and safety regulation of drilling is set out in the Health and Safety at Work etc Act 1974, with specific oil and gas controls contained in the Borehole Sites and Operations Regulations 1995, SI 1995/2038, and the Offshore Installations and Wells (Design and Construction, etc) Regulations 1996, SI 1996/913 (which, despite their title, also apply onshore).

${ }^{23}$ The diameter of the lateral wells is generally around six inches.

${ }^{24}$ DECC, 'Underground Drilling Access: Government Response to the Consultation on Proposal for Underground Access for the Extraction of Gas, Oil or Geothermal Energy (25 September 2014) <https://www.gov.uk/government/uploads/system/uploads/attachment_data/file/358521/Government_Respons e_FINAL.pdf> accessed 28 Nov 2014. Proposed amendments to the Infrastructure Bill have been made to implement this - Infrastructure HL Bill (2014-15) cls 38-43. Most shale fracking wells are around a mile or so below the surface - far below 300m.

${ }^{25}$ Donald Schön and Martin Rein, Frame Reflection: Toward the Resolution of Intractable Policy Controversies (Basic Books 1994).

${ }^{26}$ ibid 4-5.

${ }^{27}$ ibid 29.

${ }^{28}$ ibid.

${ }^{29}$ Regula Hänggli and Hanspeter Kriesi, 'Frame Construction and Frame Promotion (Strategic Framing Choices)' (2012) 56 American Behavioral Scientist 260, 266.
} 
reality and enhances a certain interpretation or evaluation of reality ... In this respect, a frame is more than an argument because it also provides a specific understanding of the world. ${ }^{30}$

Thus, although framing does of course rely on arguments, it is a strategic process whereby certain arguments are foregrounded and others are de-emphasised or ignored as part of a deliberate interpretive worldview. In addition, frames typically follow a certain formula. This can be seen in Schön and Rein's talk above of not only 'what is at issue' but also 'what is to be done', in Entman's mention earlier of framing involving diagnosis, evaluation and prescription, and in Benford and Snow's distinction between 'diagnostic' and 'prognostic' frames (to which they add 'motivational' frames). ${ }^{31}$ All of these share the idea that framing is akin to a strategic toolkit which contains different functional elements within it. To speak only of arguments would not capture this complexity.

The anti-fracking movement - which largely consists of a mix of individual activists, environmental groups and local residents - is an example of a new social movement. As intimated above by Benford and Snow's 'motivational' frames, framing is important to social movements not only because a conscious, strategic approach to framing may help to achieve desired social and policy outcomes if the battle for meaning can be won, but also because, in creating 'shared understandings of the world and of themselves', frames may help to 'legitimate and motivate collective action' ${ }^{32}$ Frames are, in other words, both a tool for trying to effect change and a recruitment rallying call for social movements.

Social movement scholars have also emphasised the way in which framing provides a useful counterpoint to overly structural approaches which account for social movement emergence and activity by reference to concepts such as political and legal opportunity structure. ${ }^{33}$ Framing, in contrast, is very much about movement actors using agency to create and communicate meaning around an issue. The question addressed in the current article is, what happens when that active agency comes up against structural public participation provision in planning and environmental permitting? Does that agency-created meaning and interpretation get properly considered within the prevailing political opportunity structure?

Geographers have also taken an interest in framing, examining, for example, how scalar frames (and counter frames) can be employed in particular social movement struggles. Thus Kurtz discusses how scale frames were used in the context of an environmental justice dispute over the siting of a polyvinylchloride factory in rural Louisiana. ${ }^{34}$ She shows how framing the issue as one of environmental racism took the dispute beyond the local to become one where national focus was appropriate. ${ }^{35}$

\footnotetext{
${ }^{30}$ ibid.

${ }^{31}$ Robert Benford and David Snow, 'Framing Processes and Social Movements: An Overview and Assessment' (2000) 26 Annual Review of Sociology 611.

${ }^{32}$ Doug McAdam, Political Process and the Development of Black Insurgency, 1930-1970 (University of Chicago Press 2010) xxi.

${ }^{33}$ Benford and Snow (n 31) 613. Lisa Vanhala, Making Rights a Reality: Disability Rights Activists and Legal Mobilization (CUP 2011).

${ }^{34}$ Hilda Kurtz, 'Scale Frames and Counter-scale Frames: Constructing the Problem of Environmental Injustice' (2003) 22 Political Geography 887.

35 ibid 906, 912.
} 
Similarly, Bickerstaff and Agyeman describe how the UK Teeside 'ghost ships' disposal controversy involved a mix of local social and environmental injustice frames and a broader appeal to 'wider scales of regulation and, in particular, a perceived failure of international enforcement of the proximity principle. ${ }^{36}$ The scale framing of the environmental justice issue also painted local Teeside as the victim of environmental harm at the hands of the large and powerful USA. ${ }^{37}$ While the ghost ships were thus framed by campaigners in terms of locally damaging impacts caused by international and national injustice, ${ }^{38}$ the campaign was in the end defeated by counter-scalar frames, whereby the industry managed to employ local, regional and national economic development, and global environmental and safety frames, to allow the ships to remain (ensuring a viable safe industry in the UK instead of unregulated break-up in countries like India). ${ }^{39}$ Finally, in a law and geography study, Hilson has examined the way in which the UK anti-nuclear weapons movement drew upon global legal frames to resist locally embedded nuclear sites. ${ }^{40}$ Although not the sole focus of the current article, scalar framing forms a key part of the discussion that follows.

\section{Framing Fracking}

Academic attention has recently turned to how fracking has been framed. In a US context, Wright, for example, has examined how frames are constructed within social movement organisations involved in anti-fracking campaigning and how they are tailored to specific audiences such as mothers with children, faith groups and self-identifying environmentalists. ${ }^{41}$ In a comparative study of the US and UK, Bomberg has looked at the frames adopted in relation to fracking in both countries. ${ }^{42}$ While she finds a considerable degree of overlap, there are also key differences in frame emphasis and resonance which she attributes to structural differences such as national approaches to risk and its regulation. Next, in an article on framing fracking in Pennsylvania, Hudgins and Poole point to the way in which pro-fracking supporters have sought to reframe the 'problem' of fracking as one about well integrity rather than fracking per se and to stop fracking being used to describe the whole range of operations associated with shale drilling rather than just the (technically correct) part involving injection of chemicals under pressure. ${ }^{43}$ Also in the US, Sica has explored how scalar frames have been used by those in favour of fracking in the US, arguing that 'a neat stack of scale frames made shale gas seem to benefit everyone',

\footnotetext{
${ }^{36}$ Karen Bickerstaff and Julian Agyeman, 'Assembling Justice Spaces: The Scalar Politics of Environmental Justice in North-east England' (2009) 41 Antipode 781, 791.

37 ibid 792

38 ibid.

39 ibid 793-8.

${ }^{40}$ Chris Hilson, 'Framing the Local and the Global in the Anti-Nuclear Movement: Law and the Politics of Place' (2009) 36 JLS 94.

${ }^{41}$ Marita Wright, 'Making it Personal: How Anti-Fracking Organizations Frame Their Messages' (2013) $24 \mathrm{~J}$ of Politics and Society 107.

42 Elizabeth Bomberg, 'The Comparative Politics of Fracking: Agenda-Setting, Networks and Framing in the US and Europe', paper delivered at the annual meeting of the UK Political Science Association, 25-27 March 2013, Cardiff, UK.

${ }^{43}$ Anastasia Hudgins and Amanda Poole 'Framing Fracking: Private Property, Common Resources, and Regimes of Governance' (2014) $21 \mathrm{~J}$ of Political Ecology 303, 314-315.
} 
encompassing 'local employment, regional supplies of cheap gas, national energy security, abundant gas for tight global markets, and a mitigating strategy for global climate change. ${ }^{44}$ Finally, in a science and technology studies-based examination of fracking in the North of England, Williams has argued that the government and other institutional actors have tended to frame the debate on fracking in technical risk terms, which fails to capture wider public frames on fracking which are not associated with risk. ${ }^{45}$ The 'deficit model' of public engagement, which involves providing the public with more facts on fracking, has also been in evidence but, as in other policy areas, is seen as unlikely to assuage the full range of public concerns. ${ }^{46}$

While the current article shares some common ground with the above emerging literature, it seeks to go beyond it in exploring UK fracking frames in more depth and in looking at scalar frames used by both sides of the policy debate. It also uniquely turns to examine whether the English planning and regulatory systems allow space for each side's framing to be heard and considered in the decision-making process.

In the UK, anti-fracking protestors and campaigners have adopted two key types of scalar frames which correspond to the concerns they have with fracking and shale gas development. First, there are 'local' frames which emphasise the local, principally environmental harms which may be caused by fracking. ${ }^{47}$ These include: the risk to human health and wildlife from water contamination ${ }^{48}$ (via ground or surface water pollution from fracking fluids, drilling muds or fluids, produced water or methane); risk to

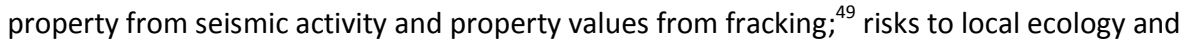
biodiversity ${ }^{50}$ risks to the landscape and local amenity from industrialisation caused by multiple well sites; ${ }^{51}$ risk of local air pollution ${ }^{52}$ (from, for example, traffic movements and hydrocarbon emissions,

${ }^{44}$ Carlo Sica, 'Scales over Shale: How Pennsylvania Got Fracked' (2013) Geography - Theses. Paper 4, $<$ http://surface.syr.edu/cgi/viewcontent.cgi?article=1003\&context=geo thesis $>$ accessed 28 Nov 2014.

${ }^{45}$ Laurence Williams, Framing Fracking: Public Responses to Potential Unconventional Fossil Fuel Exploitation in the North of England, Durham theses, Durham University, available at Durham E-Theses Online, $<$ http://etheses.dur.ac.uk/9444/> accessed 28 Nov 2014.

${ }^{46}$ ibid.

${ }^{47}<$ http://frack-off.org.uk/fracking-hell/> accessed 28 Nov 2014; Natalie Hynde, 'Why We Need an Outright Ban on Fracking in the UK, The Guardian CiF, 26 February 2014, <http://www.theguardian.com/commentisfree/2014/feb/26/natalie-hynde-ban-fracking-uk-protest-balcombe> accessed 28 November 2014; Veronika Moore and others, 'Hydraulic Fracturing for Shale Gas in the UK: Examining the Evidence for Potential Environmental Impacts' (RSPB 2014) <http://www.rspb.org.uk/Images/shale gas report evidence tcm9-365779.pdf > accessed 28 November 2014; Royal Society for the Protection of Birds (RSPB) and others, 'Are We Fit to Frack? Policy Recommendations for a Robust Regulatory Framework for The Shale Gas Industry in The UK' (20 March 2014)

$<$ http://www.rspb.org.uk/Images/shale gas summary tcm9-365778.pdf $>$ accessed 28 November 2014; World Wildlife Fund (WWF), 'WWF Position on Shale Gas in the EU' (June 2013)

$<$ http://awsassets.panda.org/downloads/wwf shale gas position.pdf> accessed 28 November 2014;

$<$ http://www.greenpeace.org.uk/climate/fracking > accessed 28 Nov 2014; FoE, 'Unconventional, Unnecessary and Unwanted: Why Fracking for Shale Gas is a Gamble the UK Does Not Need to Take' (May 2013)

<http://www.foe.co.uk/page/key-information-fracking-shale-gas > accessed 28 Nov 2014); <http://www.foescotland.org.uk/fracking $>$ (last accessed 7 October)

${ }^{48}$ See eg RSPB , 'Are We Fit to Frack?'(n 47) 14.

${ }^{49}$ eg Hynde (n 47).

${ }^{50}$ eg RSPB 'Are We Fit to Frack?' (n 47) 8-10.

${ }^{51}$ eg Greenpeace ( $n$ 47). 
including from flaring of waste gas); noise; ${ }^{53}$ and excessive water consumption affecting local supplies ${ }^{54}$ (especially in times of drought). With the above then, fracking is constructed as a local environmental problem which carries risks rather than benefits.

Next, there are 'global' frames which rather than focusing on local environmental harm, focus on global climate risks posed by shale and other unconventional oil and gas development. ${ }^{55}$ These include: the risk to climate change targets from 'direct' greenhouse gas (GHG) emissions associated with fracking ${ }^{56}$ (fugitive methane emissions, methane from venting, and $\mathrm{CO} 2$ emissions from drill rig diesel generators and gas flares), and from 'indirect' emissions ${ }^{57}$ (combustion in heat/power generation and also other life-cycle emissions in the supply and disposal chain - for example, water and waste water transport, and compressor stations used for gas supply); the risk to climate change targets from diverting investment from renewable energy sources (wind, tidal, solar), nuclear power, energy efficiency and carbon capture and storage; ${ }^{58}$ and the need to keep around two thirds of proven fossil fuel reserves in the ground to avoid dangerous warming above 2 degrees Celsius. ${ }^{59}$ With this frame, fracking is again constructed as a risk-generating problem, but the risks emphasised are global ones associated with climate change.

At the time of the 2013 protests at Balcombe, when the Green MP Caroline Lucas was arrested for allegedly blocking contractor access to the site $^{60}$ it was effectively suggested in some media quarters that the environmental movement was deliberately prioritising the local scalar frame because it would possess greater resonance with the local, predominantly Conservative population in Balcombe, who were more likely to be climate sceptics and hence less open to global, climate change framing of the problem. ${ }^{61}$ By focusing on local environmental frames, the environmental movement would be more likely to attract the support of ' $\mathrm{NIMBY}^{62}$ residents. In terms of the relationship of environmental law and climate law, this can be seen as an example of what has been called 'climate unexceptionalism', where

\footnotetext{
52 eg Frack Off ( $n$ 47).

${ }^{53}$ eg RSPB ‘Are We Fit to Frack?’ (n 47) 10.

54 eg FoE, 'Unconventional, Unnecessary and Unwanted' (n 47) 8.

55 ibid. All of the sources cited at $\mathrm{n} 47$ also give more or less equal attention to climate change.

${ }^{56}$ eg Hynde (n 47).

${ }^{57}$ eg FoE, 'Unconventional, Unnecessary and Unwanted'(n 47) 6-7.

${ }^{58}$ By keeping fossil fuel prices low, affecting or crowding out the investment market for these other activities. I.e. shale will 'outcompete renewables' (among others), increasing emissions - eg RSPB 'Are We Fit to Frack?' (n 47) 6. 59 eg RSPB, ibid 7.

${ }^{60}$ Fiona Harvey and Peter Walker, 'Caroline Lucas Among Dozens Arrested in Balcombe Anti-fracking Protest' The Guardian, 19 August 2013, <http://www.theguardian.com/environment/2013/aug/19/caroline-lucas-arrestbalcombe-anti-fracking > accessed 28 Nov 2014.

${ }^{61}$ Matthew Parris, 'The Left Hides Its Fire Behind a Smokescreen', The Times, 24 August 2013. Although others suggested that fracking might win round climate sceptics, if only to deploy climate arguments instrumentally for their own local predicament.

${ }^{62}$ Itself a scalar frame, discussed further below.
} 
there are advantages to framing issues in terms of more local environmental law rather than globally focused climate law. ${ }^{63}$

While the factual accuracy of this media assertion in the specific case in which it was raised can be called into question (because the Green MP Caroline Lucas, who was referred to, used both local and global frames in interviews after her arrest), ${ }^{64}$ it is undoubtedly true to say that having access to two different scalar frames with different resonance potential was of benefit to the anti-fracking movement because it enabled it to build a broad coalition of support across the political spectrum - with Balcombe in particular involving an alliance between broadly Conservative local residents and more radical protestors from outside. ${ }^{65}$

Besides these 'negative' scalar frames, the movement also relied on the creative and at the same time playful and hostile use of the language of fracking itself ('frack off', 'get fracked', 'frackademics' ${ }^{\text {'6 }}$ ) to frame the issue in negative terms. ${ }^{67}$ As Crooks has stated:

with its euphonious snap and vaguely obscene resonance, it is "fracking" that has captured the public imagination, and become a synecdoche for shale production as a whole. Many in the oil and gas industry dislike the word, because of its enthusiastic adoption by their opponents in the environmental movement. One executive describes it as "hate speech", and it lends itself all too readily to coinages such as "frack off" and "no fracking way". ${ }^{68}$

While not a scalar frame, this use of language can be seen as a key part of what was described above as 'motivational' framing, around which the movement has been able to effectively mobilise.

Fracking was also framed by the anti-fracking movement as an under-researched novel or new technology which poses additional risks over existing conventional oil and gas activity. It was thus presented as a source of concern that should ideally be subject to a ban or a moratorium.. Failing that, the movement argued for a new, dedicated regulatory regime or, at the very least, additional oversight

\footnotetext{
${ }^{63}$ As opposed to its reverse - climate exceptionalism - where the global climate law frame is preferred over the more localised environmental law one: Chris Hilson 'It's All About Climate Change, Stupid! Exploring the Relationship Between Environmental Law and Climate Law' (2013) 25 JEL 359.

${ }^{64}$ For video interviews with a global climate frame reference see eg $<$ http://www.theguardian.com/environment/video/2013/aug/20/caroline-lucas-protest-fracking-arrest-balcombevideo $>$; and <https://www.youtube.com/watch?v=PVIF4dYp7pM $>$ (both accessed 28 Nov 2014).

${ }^{65}$ Although unusual at first sight, such coalitions are not uncommon in the history of environmental protest - the 1990s anti-roads protests for example (eg Twyford Down) often involved such coalitions between Conservative residents and radical incoming protestors - see further Barbara Bryant, Twyford Down: Roads, Campaigning and Environmental Law (E \& FN Spon 1996).

${ }^{66}$ Referring to academics whom are said to have close ties with the fracking industry and provide it with beneficial research.

${ }^{67}$ See eg Greenpeace (n 47) ('It could frack the climate' ... 'It could frack the countryside, too') and also the extreme energy action network calling itself 'Frack Off' ( $n$ 47).

${ }^{68}$ Ed Crooks, 'The Fracking Debate', Financial Times, 23 May 2014, <http://www.ft.com/cms/s/2/0d830306-e10411e3-b59f-00144feabdc0.htm|\#axzz32QiDjKbm> accessed 28 Nov 2014.
} 
and safeguards. ${ }^{69}$ This can be seen as an example of diagnostic and prognostic framing mentioned earlier: ${ }^{70}$ fracking is diagnosed as a risky novel technology and the prognostic solution put forward is either to ban or place a moratorium on it, to have a dedicated regulatory system, or to subject it to additional regulatory control (such as exclusion zones around sensitive ecological sites, buffer zones between fracking installations and residential or other sensitive sites, or mandatory environmental impact assessment (EIA) for all unconventional oil and gas activities). ${ }^{71}$

Some media counter-framing has, similarly, been negative. Thus fracking protestors, particularly at Balcombe, were either framed as 'rent-a-mob' if they were from outside the area, ${ }^{72}$ or NIMBYs if they were local residents opposed to the drilling. ${ }^{73}$ Both of these are of course scalar frames. They also contradict each other. The first is an example of what Kurtz describes as an insider/outsider counterscale frame ${ }^{74}$ and lambasts outsiders for taking an interest in local matters that do not concern them. The second, NIMBY frame is similar, except that it belittles locals for seemingly taking an interest only in local implications. One suggests it's a matter for locals only; the other that it's not just a local matter.

$\mathrm{M}$ uch of the counter framing by government and industry has been positive, emphasising the potential benefits of fracking and downplaying the risks. Again, these benefits frames are multi-scalar in nature and indeed arguably more so here as they involve a mix of not only local and global but also the national level. First, there has been a national, predominantly economic benefits frame, stressing the number of jobs likely to be created by the industry nationally, the tax receipts that would be generated, the potential for a reduction in fuel bills, the balance of payments advantages through a decreased reliance on imports, and finally energy security. ${ }^{75}$ Second, we have seen much made of a local economic benefits frame, with attention drawn to job creation at local level and also to the economic incentives created for local communities to accept fracking wells in their area: industry has promised to pay $£ 100,000$ to local community for each exploration/appraisal well dug and that communities will further receive $1 \%$ of

${ }^{69}$ eg FoE, 'All That Glitters'(n 5).

${ }^{70}$ See main text at $\mathrm{n} 31$.

${ }^{71}$ eg FoE, 'All That Glitters' (n 5) 26; RSPB, 'Are We Fit to Frack?' (n 47) 16.

72 Antonella Lazzeri, 'The Rent-a-mob, Squatters, Ukulele players and Dale Farm Veterans Hijacking a Village Fracking Protest', <http://www.thesun.co.uk/sol/homepage/features/5036334/The-rent-a-mob-squatters-anddale-farm-veterans-hijacking-a-village-fracking-protest.html> accessed 28 Nov 2014.

73 eg Tom Bulford, 'This Country is Plagued by Nimbys', MoneyWeek, 30 May 2013,

<http://moneyweek.com/penny-sleuth-this-country-is-plagued-by-nimbys-64200/>accessed 28 Nov 2014.

${ }^{74}$ Kurtz (n 34) 909. See also Bickerstaff and Agyeman (n 36) 794, who note the use of this type of frame in the ghost ships case.

${ }^{75}$ eg DECC, 'Developing Onshore Shale Gas and Oil - Facts about 'Fracking' (December 2013) $<$ https://www.gov.uk/government/uploads/system/uploads/attachment data/file/265972/Developing_Onshore Shale Gas and Oil Facts about Fracking 131213.pdf > accessed 28 Nov 2014; David Cameron, 'We Cannot Afford to Miss Out on Shale Gas', The Telegraph, 11 August 2013, <http://www.telegraph.co.uk/news/politics/10236664/We-cannot-afford-to-miss-out-on-shale-gas.html> accessed 28 Nov 2014; Institute of Directors (IoD), 'Getting Shale Gas Working' (2013) $<$ http://www.iod.com/influencing/policy-papers/infrastructure/infrastructure-for-business-getting-shale-gasworking $>$ accessed 28 Nov 2014. 
revenues ( $2 / 3$ to local community, $1 / 3$ to county) if the well then goes into production; ${ }^{76}$ and the Government has promised to increase the amount of business rates from fracking sites that local authorities can keep from $50 \%$ to $100 \% .{ }^{77}$ However, not all the benefits frames are economic in nature there has also been a global climate change frame, pointing to US reductions in GHG emissions after the shale 'revolution' there brought about via a domestic shift from more expensive coal to cheaper shale gas. ${ }^{78}$ Here, in other words, unlike the anti-fracking movement's global climate frame which emphasises the risks of fracking to climate change, we see a global climate frame which points to potential benefits.

And while the anti-fracking movement has framed fracking as a novel technology, industry and government have instead framed it as an existing technology which, along with onshore and horizontal drilling, has been widely and safely used in the industry over a number of years. ${ }^{79}$ The existing and highly productive onshore oil well at Wytch Farm in Dorset, and its proximity to and lack of effect on the environment and house prices in Sandbanks, the highest value beachfront housing area in the UK, has often been mentioned in this regard. ${ }^{80}$ Although not shale rock and while predominantly an oil rather than gas field, horizontal drilling and fracking have been used on site in this area in the past. This emphasis on past experience and continuity is designed to provide reassurance and also to support a case for the undesirability (because unnecessary) of additional, let alone dedicated regulatory control. Again, analysing this in terms of diagnostic and prognostic framing, one can see that the diagnosis of fracking is that it is an existing technology which has been carried out without harm and without much notice in the UK in the past, and the prognosis which clearly follows from this is that, as a non-problem, it does not require any change to the existing regulatory landscape, let alone a ban. The anti-fracking movement vehemently contests such framing, arguing that earlier examples of fracking were on a much smaller scale, using much lower volumes of fracking fluid, lower pressure levels and less energy than modern 'high volume' hydraulic fracturing. ${ }^{81}$

\footnotetext{
${ }^{76}$ UK Onshore Operator's Group (UKOOG), 'Benefits of Onshore Oil and Gas', $<$ http://www.ukoog.org.uk/community/benefits $>$ and its Community Engagement Charter, $<$ http://www.ukoog.org.uk/images/ukoog/pdfs/communityengagementcharterversion6.pdf $>$ accessed 28 Nov 2014.

${ }^{77}$ Gov.uk, 'Local Councils to Receive Millions in Business Rates from Shale Gas Developments', $<$ https://www.gov.uk/government/news/local-councils-to-receive-millions-in-business-rates-from-shale-gasdevelopments $>$ accessed 28 Nov 2014; see also Nicholas Watt, 'Fracking in the UK: "We're going all out for shale," Admits Cameron', The Guardian, 13 January 2014, $<$ http://www.theguardian.com/environment/2014/jan/13/shale-gas-fracking-cameron-all-out> accessed 28 Nov 2014.

${ }^{78}$ See eg loD ( $n$ 75) 13. However, overall, globally, GHG emissions have not decreased because the US coal has instead been sold abroad, thus simply offshoring the relevant GHG emissions. The use of carbon capture and storage on generation plant using shale gas is also seldom mentioned.

${ }^{79}$ See the DECC 'Roadmap' (n 20).

${ }^{80}$ See eg ibid, and Louise Gray, 'The Town Where a Form of 'Fracking' is Already Happening', The Telegraph, 10 August 2013, <http://www.telegraph.co.uk/earth/earthnews/10233955/The-town-where-fracking-is-alreadyhappening.html> accessed 28 Nov 2014.

${ }^{81}$ eg Frack Off, 'If Fracking Has Been Happening Since 1947 What Is There To Worry About?', available at

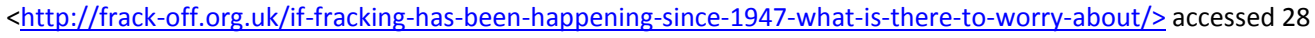
Nov 2014.
} 
The Church of England also entered the fracking debate with something of a middle way, sustainability frame. While stressing that the Church has no official policy either for or against fracking, the Chair of its group on Mission and Public Affairs issued a press release stating that fracking should not be seen just through a single (environmental) lens (or frame). ${ }^{82}$ Rather, it argued, in effect, that sustainability requires a three pillared approach, examining social and economic impacts as well as environmental ones. For the Church with its concern for poverty and inequality, it was particularly keen that potential social benefits, in terms of a reduction in fuel poverty brought about through lower bills that might arise from fracking, should not be left out of the equation. ${ }^{83}$

\section{Consideration of Frames}

The question then is to what extent some of the key frames above are recognised and considered by the English land use planning and regulatory permitting systems in their oversight of fracking well development and operation. When a planning or permit application is submitted to the relevant body (considered further below), what space is there for individuals or groups to have the way they have framed the issue of fracking considered within the planning or regulatory process? Or do Government and industry constructions of the issue receive privileged treatment so that their frames (eg economic benefit) must be taken into account but that others (eg ones which question energy policy choices involving fossil fuels) end up being ruled out of consideration in decision-making on planning permission and permitting?

The article is not seeking to prove that particular frames adopted by, for example, the anti-fracking movement have caused particular policy outcomes. ${ }^{84}$ Instead, it is attempting to explore the extent to which recent planning policy and regulatory practice on fracking in England allows for or recognises

\footnotetext{
${ }^{82}$ See 'Statement from Church of England on Fracking', 16 August 2013, $<$ https://www.churchofengland.org/media-centre/news/2013/08/statement-from-church-of-england-onfracking.aspx $>$ accessed 28 Nov 2014.

${ }^{83}$ Although many, including industry observers, have queried whether unconventional gas will reduce gas prices given the structure of the European gas market - see eg Deutsche Bank, 'European Gas: A First Look At EU Shale-Gas Prospects' (2011) Global Markets Research, Commodities Special Report, $<$ http://www.fraw.org.uk/files/extreme/deutsche bank 2011.pdf $>28$ Nov 2014; Tom Bawden, "Baseless Economics': Lord Stern on David Cameron's Claims that a UK Fracking Boom Can Bring Down Price of Gas', The Independent, 3 September 2013, <http://www.independent.co.uk/news/uk/politics/baseless-economics-lordstern-on-david-camerons-claims-that-a-uk-fracking-boom-can-bring-down-price-of-gas-8796758.html> accessed 28 Nov 2014.

${ }^{84}$ There is a significant literature on the relationship between social movements and outcomes, and a somewhat smaller subset of that literature which explores the effect of movement framing on outcomes. While the outcomes examined are varied, many studies focus on the impact of collective action (including framing) on particular legislative or policy changes - so called 'direct' outcomes. See further Daniel Cress and David Snow, 'The Outcomes of Homeless Mobilization: The Influence of Organization, Disruption, Political Mediation, and Framing' (2000) 105 American Jof Sociology 1063; Holly McCammon and others, 'Movement Framing and Discursive Opportunity Structures: The Political Successes of the U.S. Women's Jury Movements' (2007) 72 American Sociological Rev 725; Francesca Polletta and M Kai Ho, 'Frames and Their Consequences', in Robert Goodin and Charles Tilly (eds), The Oxford Handbook of Contextual Political Analysis (OUP 2004) 187.
} 
certain frames in the debate on whether and under what conditions fracking well sites should be given the go-ahead in terms of planning permission and regulatory permitting. As will be seen below, a key global climate change framing of fracking - which constructs it as a dangerous continuation of an overreliance on carbon-based fuels in place of renewables or energy efficiency - is invariably excluded as an off-limits argument which cannot be considered by planning authorities in their decisions on fracking well sites or by environmental regulators in their permitting decisions on such sites. Such a frame will therefore not work within the formalities of the particular procedure - whether planning or regulatory. It is not one that these procedures will accept as a legitimate construction of the issue which can be considered by the relevant public decision-makers.

Thus, the article is an examination of whether the anti-fracking movement and its opponents have had their respective framing or construction of fracking accepted within planning and regulatory policy. It is concerned with which frames are privileged by the planning and regulatory decision-making framework and, on the flip side, which frames have been effectively ruled out for from being effectively heard within those frameworks. To this extent, the article shares something in common with the existing literature on public participation in environmental law. In a recent article, Lee and others, have examined the limited scope for meaningful public participation in significant climate infrastructure projects involving windfarms and carbon capture and storage (CCS) facilities. ${ }^{85}$ Those two cases fall within the remit of the Planning Act $2008^{86}$ which provides for 'development consent' decisions on nationally significant infrastructure projects to be taken centrally by the relevant Secretary of State, having first been examined by the Planning Inspectorate. Ultimately, the Secretary of State's decision must be made 'in accordance with any relevant national policy statement', with certain defined exceptions. $^{87}$

In the case of windfarms and CCS, the relevant national policy statements effectively rule out a number of key public concerns from being of relevance in decision-making. What this means is that '[f]or major wind and CCS infrastructure projects ... the limitations on what counts as a good reason to challenge proposals, leaves very little space for participation.' In practice, as Lee and others note, '[t]here is actually likely to be little that participating publics can contribute to the final decision: noise, aesthetics, protected sites, alternative sites, concern about the effectiveness and adequate regulation of new technologies, are all more or less out of bounds. ${ }^{, 88}$ There are therefore clear parallels with the work of Lee and others - both pieces being concerned with what can be considered as part of public participation and what is effectively ruled out of bounds. However, the legal context is different in the case of fracking. Although the Government consulted on subjecting onshore oil and gas development above certain volumes ${ }^{89}$ to the 2008 regime, it eventually decided to leave it under local democratic

\footnotetext{
${ }^{85}$ Maria Lee and others, 'Public Participation and Climate Change Infrastructure' (2013) 25 JEL 33, 53.

${ }^{86}$ As amended (in particular by the Localism Act 2011).

${ }^{87}$ eg if the Secretary of State is satisfied that the adverse impact of the proposed development would outweigh its benefits.

${ }^{88}$ Lee and others (n 85) 60.

${ }^{89}$ Many of the initial applications for planning permission seen in recent years for shale gas drilling would thus not in any event have come within the 2008 regime as they have typically been for exploration activities. The 2008 Act would only have been applicable later, with applications for production operations.
} 
control within the standard planning system described further below. ${ }^{90}$ The current article is also applying a different theoretical perspective (framing) to a different practical problem (fracking, as opposed to windfarms and CCS). The lessons learnt from this different perspective have the potential to add to our understanding of decision making in respect of controversial infrastructure, whether or not such infrastructure falls within the scope of the 2008 Act.

\section{Planning and Regulatory Policy and Practice}

\section{Planning}

Drilling and fracking a new oil or gas well in the UK requires planning permission, and permission is required for each phase - exploration, appraisal and production. Applications for planning permission in England are made to Mineral Planning Authorities (MPAs). ${ }^{91}$ Provision is made for public involvement. Under the online Planning Practice Guidance (PPG), operators are 'encouraged' to carry out preapplication engagement with the local community. ${ }^{92}$ (Only in relation to windfarms has pre-application community engagement been made compulsory.) ${ }^{93}$ Members of the UK Onshore Oil and Gas (UKOOG) industry trade association have also committed to voluntary pre-application consultation with local communities as part of its Community Charter. ${ }^{94}$

Once an application has been submitted there will then be further public consultation, involving notification and publicity of the application and enabling the public to make representations. ${ }^{95}$ There was some controversy when the Government altered the notification element, removing the requirement to notify specific landowners and tenants of the planning application where only underground operations are involved. ${ }^{96}$ Where an environmental impact assessment (EIA) is required, ${ }^{97}$

\footnotetext{
${ }^{90}$ Department of Communities and Local Government (DCLG), 'Major Infrastructure Planning: Extending The Regime to Business and Commercial Projects: Summary of Responses and Government Response' (June 2013), $<$ https://www.gov.uk/government/uploads/system/uploads/attachment data/file/208049/Major infrastructure planning - extending the regime to business and commercial projects summary of responses and government response.pdf $>$ accessed 28 Nov 2014. However, this was to be kept under review.

${ }^{91}$ This may be the County Council, a Unitary Authority, or the National Park Authority.

${ }^{92}$ PPG, 'Before Submitting an Application', Paragraph: 009 Reference ID: 20-009-20140306, $<$ http://planningguidance.planningportal.gov.uk/blog/guidance/before-submitting-an-application/who-can-beinvolved-at-the-pre-application-stage/local-people-at-the-pre-application-stage/> accessed 28 Nov 2014.

${ }_{93}$ The Town and Country Planning (Development Management Procedure and Section 62A Applications) (England) (Amendment) Order 2013, SI 2013/2932. The regs were introduced under amendments introduced by the Localism Act 2011. Accusation of double standards have been made in this respect, with windfarms being subject to more stringent conditions than fracking because of alleged Government antipathy towards the former and enthusiasm for the latter.

${ }^{94}<$ http://www.ukoog.org.uk/images/ukoog/pdfs/communityengagementcharterversion6.pdf $>$ accessed 28 Nov 2014.

${ }_{95}$ See the Town and Country Planning Act 1990 and the Town and Country Planning (Development Management Procedure) (England) Order 2010, SI 2010/2184.

${ }^{96}$ The Town and Country Planning (Development Management Procedure and Section 62A Applications) (England) (Amendment No. 2) Order 2013, SI 2013/3194.
} 
that has additional consultation and public participation requirements associated with it. ${ }^{98}$ Even where an EIA is not required, an environmental risk assessment (ERA) must be carried out for all shale gas operations involving hydraulic fracturing, as a matter of 'good practice' imposed by DECC. ${ }^{99}$ The ERA also provides for the participation of stakeholders including local communities 'as early as practicable' but in any case before applying for planning permission. ${ }^{100}$ Where an EIA does turn out to be needed, the ERA can help to inform this (and the ERA may also be used to inform risk assessments needed for environmental permitting). ${ }^{101}$

Planning law requires that applications for planning permission must be determined in accordance with the development plan, unless material considerations indicate otherwise. ${ }^{102}$ The relevant development plan here will be the Minerals Local Plan. ${ }^{103}$ There is a wide range of material planning considerations which MPAs should take into account. These will include, inter alia, any environmental statement made as part of an EIA, an ERA, government planning policy in the shape of the National Planning Policy Framework (NPPF) and the Minerals section of the online PPG as well as other relevant government policy, for example on energy. ${ }^{104}$ Public representations which relate to any material planning consideration must also be taken into account by the MPA.

In terms of particular frames on fracking being given space within the planning process, we are concerned here with the planning decision-taking stage and any associated ERA and EIA, though of course framing will also be relevant during public participation at the plan making stage, as Minerals Local Plans are drawn up. ${ }^{105}$ It is also worth distinguishing between, on the one hand, the ability to raise

\footnotetext{
97 Under the Town and Country Planning (Environmental Impact Assessment) Regulations 2011, SI 2011/1824. If a development falls within Sch 1 of the Regulations, then an EIA is mandatory. Operations where more than 500 tonnes of oil or 500,000 cubic metres of gas will be extracted per day fall under Sch 1 . For Sch 2 projects, EIA is required if the development is likely to have a significant environmental effects. Regarding Sch 2, the Minerals PPG states that 'it is unlikely that an [EIA] will be required for exploratory drilling operations which do not involve hydraulic fracturing' (Paragraph: 119 Reference ID: 27-119-20140306). In 2013 the European Parliament proposed an extension of the EIA Directive to make EIA mandatory (i.e. Sch 1) for all unconventional oil and gas development involving fracking, including at the exploration stage; however, this amendment was subsequently blocked by Member States including the UK. In practice, the UK onshore industry has agreed, on a voluntary basis that all applications involving fracking will be subjected to an EIA.

${ }^{98}$ See Part 5 of the TCP (EIA) Regulations 2011 (n 97) and art 13 of the TCP (DMP) (England) Order 2010 (n 95 ).

99 'Roadmap' (n 20) 16.

100 ibid.

101 ibid and ministerial statement (n 15).

102 s 70(2) of the Town and Country Planning Act 1990 and s 38(6) of the Planning and Compulsory Purchase Act 2004. However, 'Where the development plan is absent, silent or the relevant policies are out of date, paragraph 14 of the [NPPF] requires the application to be determined in accordance with the presumption in favour of sustainable development unless otherwise specified' (PPG, 'Determining a Planning Application', Paragraph: 006 Reference ID: 21b-006-20140306).

103 Under the Planning \& Compulsory Purchase Act 2004 and The Town and Country Planning (Local Planning) (England) Regulations 2012, SI 2012/767.

${ }^{104}$ In the form of the Government's Annual Energy Statement (see further the main text an $\mathrm{n} 120$ below).

${ }^{105}$ On consultation at this stage, see regs 18-20 of the TCP (LP) (E) Regs ( $n$ 103). Global climate frames will be relevant at that stage under s 19(1A) of the Planning and Compulsory Purchase Act 2004 (as amended by s 182 of the Planning Act 2008), which states: 'Development plan documents must (taken as a whole) include policies
} 
alternative frames as part of public participation in the ERA/EIA and planning decision-taking process and, on the other, whether the legal context allows for them to be considered. In principle all types of framing can be aired; but not all types will be taken into account. As will be seen, ERAs/EIAs focus on particular issues and Government planning policy limits the ability for certain frames to count as material considerations. ${ }^{106}$

So which frames will be captured by the EIA process, where one is required by law? Article 3 of the EIA Directive 2011/92/EU ${ }^{107}$ requires consideration of the direct and indirect effects of a project on both the local environment and human health, and the global climate. ${ }^{108}$ Both local and global frames will therefore be captured for fracking projects which cross the thresholds for triggering an EIA. An examination of a recent EIA submitted by Caudrilla confirms this, with the environment statement covering both effects on for example, local water, air quality and biodiversity, and effects on climate change. ${ }^{109}$ Nevertheless, the precise scope of what counts as 'indirect' greenhouse gas (GHG) emissions is not entirely clear. ${ }^{110}$ It clearly refers to offsite carbon impacts such as, for example, the GHG emissions associated with the production and transport of diesel used for on-site power generation, or the treatment and disposal of waste water. However, it could conceivably also refer to emissions from eventual use of production stage shale gas as a fuel in gas fired power stations or for domestic heating. ${ }^{111}$ Because Caudrilla's application relates to an exploration well rather than a production well,

designed to secure that the development and use of land in the local planning authority's area contribute to the mitigation of, and adaptation to, climate change.'

${ }^{106} \mathrm{Cf}$. environmental permitting below, where there is no equivalent of planning guidance which seeks to spell out what should and should not be regarded as a material consideration (with the guidance also itself being a material consideration). NB also that, according to Woolf J (as he then was), in Gransden (EC) \& Co Ltd v Secretary of State for the Environment and Gillingham BC [1986] JPL 519, planning policy cannot make a matter which is a material consideration into an irrelevant consideration - ultimately it is up to the courts to decide what is a material consideration. The case also states that the fact that a body has to have regard to a policy does not mean that it necessarily needs to follow the policy.

107 [2011] OJ L26/1.

${ }^{108}$ The Commission has published non-binding guidance on how climate change issues should be incorporated into an EIA - see European Commission 'Guidance on Integrating Climate Change and Biodiversity into Environmental Impact Assessment' (2013) <http://ec.europa.eu/environment/eia/pdf/EIA\%20Guidance.pdf> accessed 28 Nov 2014. The Environment Agency's draft technical guidance on onshore oil and gas exploratory operations (Environment Agency, 'Onshore Oil and Gas Exploratory Operations: Technical Guidance' (Consultation Draft, August 2013) <https://consult.environment-agency.gov.uk/file/2582905> accessed 28 Nov 2014 , merely speaks, in relation to EIA, of the need for 'an assessment of the impact of the development on emissions of greenhouse gases' (9).

${ }^{109}$ Caudrilla and Arup, 'Caudrilla Bowland Ltd, Temporary Shale Gas Exploration Preston New Road Lancashire: Environment Statement' (May 2014) <http://cuadrillaresources.com/wpcontent/uploads/2014/06/PNR ES Vol1 Environmental-Statement1.pdf > accessed 28 Nov 2014.

${ }^{110}$ The Commission guidance ( $\mathrm{n}$ 106) para 4.1.1, Table 6 is not clear on this. It distinguishes between 'direct GHG [greenhouse gas] emissions caused by the construction, operation, and possible decommissioning of the proposed project, including from land use, land-use change and forestry' and 'indirect GHG emissions due to increased demand for energy; indirect GHG emissions caused by any supporting activities or infrastructure which is directly linked to the implementation of the proposed project (eg transport, waste management).'

${ }^{111}$ It is hard to see where this 'final fuel use' fits into the Commission guidance on indirect emissions quoted at $\mathrm{n}$ 110 above. It could conceivably be argued that it is an example of 'indirect GHG emissions due to increased demand for energy', in which case the guidance goes on to suggest (para 4.1.2, Table 7) that the following 
the EIA considers only direct and indirect climate impacts arising from activities relating to the exploratory gas extraction process and does not consider GHG emissions from the eventual, hoped for production stage, including the final use of gas as a fuel. ${ }^{112}$ This complies with the Minerals PPG, which states that 'Individual applications for the exploratory phase should be considered on their own merits. They should not take account of hypothetical future activities for which consent has not yet been sought, since the further appraisal and production phases will be the subject of separate planning applications and assessments'. ${ }^{113}$ (That said, in a separate part, the EIA does in fact seek to justify shale gas exploration in the context of renewables and climate change, arguing for a transition role for natural gas in the move away from fossil fuels. $)^{114}$

While detailed guidance on ERAs is yet to appear, a ministerial statement notes that 'Licensees will be required to carry out a comprehensive high-level assessment of environmental risks, including risks to human health, and covering the full cycle of the proposed operations, including well abandonment. ${ }^{, 115}$ However, as with EIA above, the 'full cycle' is actually far from full because the statement goes on to observe that:

The scope of these assessments would naturally be framed by the operations proposed, so that prospective future production operations would not be in scope for an assessment drawn up for exploration activities. ${ }^{116}$

Commenting on this, Williams states that '[I]imiting the scope of ERA's so as to not take into account potential future production operations when assessing exploration activities somewhat 'compartmentalises' the issue. ${ }^{117}$ What it means is that the ERA consultation opportunities, like those for EIA, will, certainly at exploration stage, fail to consider global climate frames which involve issues of final fuel use.

Moving on from environmental impact and risk assessments to planning decision-taking, planning practice guidance for onshore oil and gas development was initially published in July $2013 .{ }^{118}$ This guidance was subsequently replaced in March 2014 by the 'Planning for Hydrocarbon Extraction' part of the 'Minerals' section of the online PPG. Many local environmental frame issues are ones which can be considered by MPAs. Thus, for example, the new guidance states that 'planning conditions may be imposed to prevent run-off of any liquid from the pad, and to control any impact on local amenity (such as noise)', that 'Mineral planning authorities will ... need to consider how issues of noise and visual

questions be asked: 'Will the proposed project significantly influence demand for energy?' and 'Is it possible to use renewable energy sources?' The latter sits uncomfortably with UK government guidance at eg nn 120 and 146 below.

${ }^{112}$ Caudrilla and Arup (n 109) ch 8.1, p 107.

${ }^{113}$ Paragraph: 120 Reference ID: 27-120-20140306.

${ }^{114}$ Caudrilla and Arup (n 109) ch 1.2, p 5.

115 (n 22).

${ }^{116}$ ibid.

${ }^{117}$ Williams (n 45) p 22.

${ }^{118}$ DCLG, 'Planning Practice Guidance for Onshore Oil and Gas', July 2013, $<$ https://www.gov.uk/government/uploads/system/uploads/attachment data/file/224238/Planning practice gui dance for onshore oil and gas.pdf $>$ accessed 28 Nov 2014. 
impact [from venting and flaring] will be addressed' and that they are 'responsible for ensuring the wells are abandoned and the site is restored.' Similarly, the 'storage on-site and the traffic impact of any movement of [waste] water' is stated to be 'of clear interest to local authorities'. However, in relation to other issues concerning well design, construction, operation, waste and so on which are covered by separate regulatory regimes, the guidance states that 'mineral planning authorities should assume that these regimes will operate effectively.' In other words, planning does not cover every local frame issue of concern, but the assumption is that other specialist regulatory regimes will do so. In this respect, the position regarding fracking is no different to any other area of environmental law, where cases such as Gateshead ${ }^{119}$ and planning policy guidance (eg the old PPG 23$)^{120}$ have long policed the relationship between planning and pollution control, making sure that each stays on its own territory and that unnecessary overlaps are avoided.

Paragraph 94 of the NPPF allows, in general terms, for consideration of a global climate frame at the plan making stage, stating that 'Local planning authorities should adopt proactive strategies to mitigate and adapt to climate change'. However, the specific hydrocarbons PPG then excludes certain aspects of that global, climate frame at the decision taking stage. Having posed the question of whether MPAs 'need to assess demand for, or consider alternatives to oil and gas resources when determining planning applications', the guidance replies that they 'should take account of Government energy policy, which makes it clear that energy supplies should come from a variety of sources. This includes onshore oil and gas, as set out in the Government's Annual Energy Statement published in October 2013'. ${ }^{121}$ This clearly rules out (at any stage) consideration by MPAs of the 'eventual use' type of indirect climate change impacts of shale gas adverted to above in discussing EIA/ERA. They have to assume that energy supplies from all sources are equally valid and they are not permitted to consider the reduced greenhouse gas potential of alternative supplies such as renewables or ('demand') of energy efficiency measures.

One marked difference between the July 2013 PPG and the new online PPG on hydrocarbons lies in relation to economic frames. The old guidance provided clear space for pro-fracking economic frames, stating that:

Mineral extraction is essential to local and national economies. As stated in paragraph 144 of the National Planning Policy Framework, minerals planning authorities should give great weight to the benefits of minerals extraction, including to the economy, when determining planning applications. ${ }^{122}$

\footnotetext{
${ }^{119}$ Gateshead MBC v Secretary of State for the Environment [1995] Env LR 37.

${ }^{120}$ Planning Policy Guidance Note 23: Planning and Pollution Control (PPG23), published in 1994 and subsequently replaced by a similar planning policy statement (PPS 23) on the issue. Both have since been replaced by the National Planning Policy Framework (NPPF).

${ }^{121}$ PPG, 'Planning for Hydrocarbon Extraction', Paragraph: 124 Reference ID: 27-124-20140306. The Annual Energy Statement referred to is DECC, 'Annual Energy Statement 2013' (October 2013) <https://www.gov.uk/government/uploads/system/uploads/attachment data/file/254250/FINAL PDF of AES 20 13 - accessible version.pdf $>$ accessed 28 Nov 2014.

${ }^{122}$ (n 118) para 66, p 15.
} 
The new guidance no longer includes this benefits frame (although such a frame remains, in generic form, in the minerals section of the main NPPF Document). ${ }^{123}$ However, it does still speak in terms of there being a 'pressing need' for exploratory drilling to establish whether there are sufficient recoverable quantities of unconventional gas for economically viable full scale production. ${ }^{124}$

\section{Regulatory Policy and Practice}

The key regulatory system governing fracking in England is the Environmental Permitting regime, operated by the Environment Agency. A fracking operator is likely to have to apply for one or more regulatory permits under the Environmental Permitting (England and Wales) Regulations $2010^{125}$ for a range of different operations or activities involved. ${ }^{126}$ Thus for any particular drilling site, a permit may be required, inter alia, ${ }^{127}$ for a mining waste operation, ${ }^{128}$ a groundwater activity, ${ }^{129}$ a radioactive substances activity, ${ }^{130}$ and an Industrial Emissions Directive (IED) installation for the incineration of hazardous waste. ${ }^{131}$ Under regulation 59 , the Agency is obliged ${ }^{132}$ 'to prepare and publish a statement of its policies for complying with its public participation duties.' This it has done, in the shape of its 'Public Participation Statement ${ }^{\prime 133}$ which explains how the public can participate in decisions on applications for environmental permits and in the development of rules for standard permits.

The Statement notes the existence of a policy of increased consultation on applications at sites where the Agency considers there is, or is likely to be a 'high degree of public interest'. This is tailored to specific local circumstances but may include one or more of: extending the consultation period; wider

\footnotetext{
${ }^{123}$ The document (DCLG, 'National Planning Policy Framework' (March 2012)), which remains in force, contains the following generic minerals benefit reference which will include oil and gas: 'When determining planning applications, local planning authorities should: give great weight to the benefits of the mineral extraction, including to the economy' (para 144, p 34).

124 'Planning for Hydrocarbon Extraction', Paragraph: 091 Reference ID: 27-091-20140306.

${ }^{125}$ SI 2010/675, as amended.

${ }^{126}$ See the Roadmap (n 20).

${ }^{127}$ For a fuller list, see ibid p 28, and also Economic Affairs Committee, 'The Economic Impact on UK Energy Policy of Shale Gas and Oil' (HL

${ }^{133}$ Environment Agency, 'Working Together: Your Role in Our Environmental Permitting: Our Public Participation Statement', $2^{\text {nd }}$ edn (February 2010) < https://www.gov.uk/government/publications/environmental-permittingpublic-participation-statement> accessed 28 Nov 2014.
} 
advertising; and consulting on the draft permit and decision document (ie in effect, allowing a second consultation on the draft decision to issue a permit). ${ }^{134}$ However, this has not been without controversy, with Caudrilla's Balcombe application apparently not having been classified as of high public interest, despite mass public protest, significant police presence, and widespread media coverage. ${ }^{135}$

There has also been controversy in relation to the Environment Agency consultation on applying 'standard rules' for onshore oil and gas environmental permits, ${ }^{136}$ rather than, as at present, issuing 'bespoke permits'. ${ }^{137}$ In consultation terms, while any new standard rules will themselves have been consulted upon, they are henceforth an off-the-peg set of rules which can be applied to future permit applications without triggering consultation requirements for each of those applications. ${ }^{138}$ Standard rules are aimed at speeding up the regulatory process. However, in part due to pressure from Public Health England, it seems that any permit applications involving hydraulic fracturing will still require a bespoke permit and that the public will therefore continue to have a right to participate and put across their frames in relation to each application. ${ }^{139}$

The issue of what frames will be acknowledged and heard is slightly different here to the section above on planning. There, it was a matter of seeing whether a particular frame had been allowed for or, conversely, been effectively excluded from consideration in the EIA (where required) and ERA or by the planning policy. Here, in contrast, the environmental permitting rules and the Environment Agency's policy guidance contain either no (environmental permitting) or much less detail (Agency guidance) on what types of issues will and won't be considered as part of public consultation on permits. The Participation Statement speaks only of 'relevant' information on 'the potential environmental or human health impacts of the activity, in the immediate vicinity or further afield.' And the draft technical guidance on onshore oil and gas merely notes that: 'Only comments directly relevant to the permit are taken into account when determining the application. Other comments will not be considered. ${ }^{140}$ But of

\footnotetext{
${ }^{134}$ ibid paras 4.8-4.9.

${ }^{135}$ See FoE's response in $<$ https://consult.environmentagency.gov.uk/portal/ho/ep/src/no10/standard rules no10?pointld=ID-2825342-QUESTION-VIEWS-ON-THESTANDARD-RULES-CONSULTATION-NO-10-ONSHORE-OIL-AND-GAS-EXPLORATIONS\&do=view $>$ accessed 28 Nov 2014. Though, as noted earlier, this was not an application involving fracking as such. For the Agency's explanation of why it was not a case requiring extended consultation, see the outcome document, below $n 146, p 33$ (essentially stating that it viewed it as non-complex, short duration and low risk).

${ }^{136}$ These rules will apply within a 'standard permit'.

${ }^{137}$ Environment Agency, 'Draft Standard Rules Consultation No.10 - Standard Rules for the Environmental Permitting Regulations' (17 February 2014) <https://consult.environmentagency.gov.uk/portal/ho/ep/src/no10/standard rules no10?pointld=2825343\#document-2825343> accessed 28 Nov 2014.

${ }^{138}$ Unless an installation governed by the IED (ex IPPC Directive) ( $n$ 131) is involved - see Environment Agency ( 133) para 3.2 - where even a standard permit application will require consultation.

${ }^{139}$ (n 135).

${ }^{140}$ Environment Agency, 'Onshore Oil and Gas Exploratory Operations: Technical Guidance' (n 108) $12 .$.
} 
course, just like planning decisions, ${ }^{141}$ permitting decisions sit within a general administrative law context in which decision makers are expected to take into account relevant considerations and to ignore irrelevant ones. In principle, any relevant Agency guidance will clearly be a relevant consideration, as will an ERA or EIA; and, in fracking cases and others involving energy, so too may government energy and climate policy be one. ${ }^{142}$ In the end, as will be seen below, if government policy documents clearly favour a particular energy choice (gas) and account for this within an overall, up-todate climate policy, but this government framing is irreconcilable with alternative social movement framing of that energy choice, then the government frames will prove more powerful because they are the ones that are likely to be followed by decision makers and upheld by the courts. ${ }^{143}$ Unlike planning above, where government planning policy excludes certain frames, with permitting here, it is the positive presence of government policy frames which are a relevant consideration and which will typically win over alternative climate framing. ${ }^{144}$

It is possible to obtain a fuller picture by piecing together from recent permitting decision outcome documents what the Agency has considered directly relevant and hence which frames are likely to be accepted and which excluded in practice and not just in principle. The decision documents focused on are those which involve hydraulic fracking or another form of pressurised well stimulation such as acid fracturing ${ }^{145}$ and which have appeared on the Environment Agency's online consultation portal. ${ }^{146}$ The

\footnotetext{
${ }^{141}$ Where the notion of a 'material consideration' is a planning specific example of a relevant consideration, with more of a visible history of what will and won't count as one; and where planning guidance, itself a material consideration, is also capable of spelling out what factors are to be regarded as material considerations and which are to be ignored.

${ }^{142}$ In the shape of eg the government's Annual Energy Statement (n 121) and government policy on shale gas and climate change - see DECC, 'Fracking UK Shale: Climate Change' (February 2014) <https://www.gov.uk/government/uploads/system/uploads/attachment data/file/277220/Climate Change.pdf > accessed 28 Nov 2014.

${ }^{143}$ To similar effect in an airport expansion and climate context, see Barbone $v$ Secretary of State for Transport [2009] EWHC 463, where it was held that it was perfectly proper for the planning decision maker to have determined the appeal 'in accordance with relevant and up to date national policy' (on air transport capacity, including its climate impacts) which was a material consideration. Although a planning case, the handling of policy is likely to be similarly applicable in the permitting context.

${ }^{144}$ As happened in Barbone, ibid, where the claimants' alternative climate framing of aviation expansion, which it was arguing for as a material consideration, ultimately failed, with the court preferring to accept the government's recent policy on aviation which had considered climate change (albeit coming to a different approach and conclusion to that of the claimants).

${ }^{145}$ Otherwise known as fracture acidisation or, as referred to in the decision documents, an 'acid squeeze' (with hydrochloric acid as the relevant acid). For the similarities to and differences from hydraulic fracturing, see <http://www.canadianinsight.com/index files/Page350.htm> accessed 3 December 2014.

${ }^{146}<$ https://consult.environment-agency.gov.uk/portal> accessed 3 December 2014. Cf Caudrilla Balcombe (Lower Stumble) - Environment Agency, 'Determination of an Application for an Environmental Permit under the Environmental Permitting (England and Wales) Regulations 2010', draft permit number EPR/AB3307XD, <https://consult.environment-agency.gov.uk/file/2585024> accessed 28 Nov 2014. Although Balcombe was in many ways the epicentre of the recent controversy over fracking, it did not involve fracking of any kind (though the fear, as with many such sites, was that fracking would occur at some later stage). While not included as a main
}

Comment [A1]: I have made significant changes to the following paras (ending at the next comment like this), so track changes was becoming unmanageable. You may therefore want to read through them to double check.

I have followed your suggestion of citing page numbers in relevant docs as appropriate. 
first two - Rathlin Energy (Crawberry Hill) ${ }^{147}$ and and Rathlin Energy (West Newton) ${ }^{148}$ - are final decision documents and involve mining waste operations and IED installations for the relevant gas flares. The other, more recent ones - Caudrilla Bowland (Preston New Road) ${ }^{149}$ and Caudrilla Elswick (Roseacre Wood) $)^{150}$ - are draft decision documents, subject to a further round of public consultation. In addition to a mining waste operation and IED flaring installation, these cover groundwater and radioactive substances, with the last of these dealt with via separate permits with their own decision documents. These relatively limited numbers reflect the fact that application of the environmental permitting regime to new onshore drilling activity involving fracking is still in its infancy.

A decision outcome document explains how the Agency has considered the application and provides reasons for its decision to the public and other interested parties. The emphasis at the start of all of these documents is very much on showing how the Agency has taken relevant factors into account in its decision making. At the end there is an annex detailing responses to public consultation and the Agency's reasoning on these. It is particularly this latter annex which enables one to see whether particular frames have been considered or not, but the earlier parts are also instructive.

It can be seen from all of the decision documents that the Environment Agency will consider many key local environmental impacts of concern raised by the public, such as the potential effects of waste drilling muds or fluids, produced water and flowback fluids on local groundwater supplies. ${ }^{151}$ More striking is the Agency's treatment of global climate frames. Here there is a notable difference between the earlier final documents and the more recent draft documents. The earlier two take into account

focus for this reason, it is however mentioned in passing in footnotes below because of its high public profile and close association with fracking.

${ }^{147}$ Environment Agency Permitting Decisions, Bespoke Permit EPR/BB3000KC, $<$ https://www.gov.uk/government/uploads/system/uploads/attachment data/file/308157/Decision document.p $\mathrm{df}>$ accessed 28 Nov 2014.

${ }^{148}$ Environment Agency Permitting Decisions, Bespoke Permit EPR/BB3001FT, $<$ https://www.gov.uk/government/uploads/system/uploads/attachment data/file/307848/Decision document.p df $>$ accessed 28 Nov 2014.

${ }^{149}<$ https://consult.environment-agency.gov.uk/portal/npsapp/ppd/dd cuad?pointld=3097799 > accessed 2 December 2014.

${ }^{150}<$ https://consult.environmentagency.gov.uk/portal/npsapp/dd cuadrilla elswick limited/dd cuade?pointld=3099573> accessed 2 December 2014.

${ }^{151}$ Crawberry Hill (n 147) pp 23-24, 35-38; West Newton (n 148) pp 23-24, 35-38; 'Draft Decision Document Cuadrilla Bowland Limited at Preston New Road Exploration Site', permit no. EPR/AB3101MW/A001 (Preston New Road) (n 149) pp 19-28, 81-86; Environment Agency Permitting Decisions, 'Consultation on our Decision Document Recording our Decision Making Process', permit no. EPR/BB3800FQ/A001 (Roseacre Wood) (n 150) pp 19-28, 8287. 
issues such as fugitive methane emissions, and the venting and flaring of methane. ${ }^{152}$ However, although these issues are clearly climate related, in these earlier cases the terminology of climate change appears to be studiously avoided. In other words, although methane, a key GHG, is discussed, this is done in a muted technical manner. There is mention of 'pollution' ${ }^{153}$ from the flare, but no inclusion of the more politically charged language of climate change. ${ }^{154}$

In contrast, the more recent draft decision documents do specifically mention and explicitly address global climate change in the context of the flaring installation, where the Agency now obviously (and rightly) regards this as a legal obligation under the IED. The documents discuss GHG emissions from $\mathrm{CO} 2$ and methane from the flare, noting the former as being 'clearly' a pollutant for the purposes of the IED and concluding that flaring is BAT (the best available technique) for the waste gas. ${ }^{155}$

However, across all of the above documents, it can be seen that the Agency will not consider anything considered to be outside the scope of an application for the relevant permit. Hence it will not examine, inter alia, indirect global climate change impacts of the final use of using shale gas as a fuel in, for example, power generation, which is stated to be a matter of government climate change policy. In all of the relevant decisions, the Agency states that comments received in the public consultation relating to energy and climate change will not be considered because:

Policy is made by the Government and the policy on the exploitation of Shale Gas is no different to that of any other fossil fuel. The policy states 'We aim to maximise the economic recovery of oil and gas from the UK's oil and gas reserves, taking full account of environmental, social and economic objectives'. ${ }^{156}$

In other words, while local environmental frames can be employed by social movement actors within the Environment Agency's permitting consultation process, global climate frames are only partly allowed within the process in the shape of submissions regarding direct GHG-related emissions from, for example, flaring (though, once received by the Agency, these have until recently been stripped down to

\footnotetext{
${ }^{152}$ Crawberry Hill (n 147) pp 40-41; West Newton (n 148) pp 40-41. See also Balcombe (n 146) pp 27-28. ${ }^{153}$ eg West Newton (n 148) p 20.

${ }^{154}$ Crawberry Hill (n 147) pp 20, 24; West Newton (n 148) pp 20, 24. See also Balcombe (n 146) pp 14, 16, 18

${ }^{155}$ Preston New Road (n 151) p 57; Roseacre Wood (n 151) p 57.

${ }^{156}$ Crawberry Hill (n 147); West Newton (n 148); Preston New Road (n 151) p 101; Roseacre Wood (n 151) p 102. This wording is used in all four relevant decision documents. None provides a citation reference to the relevant government policy. The wording seems to have come from a historical version of the DECC website at 1 (<http://mycouncil.surreycc.gov.uk/Data/Planning\%20and\%20Regulatory\%20Committee/20111109/Agenda/Item \%207\%20-\%20Horsehill.pdf $>$ ). Nevertheless, the current UK Annual Energy Statement 2013 (n 121) containing government energy policy is very similar in stating: 'With oil and gas remaining key elements of the energy system for years to come (especially for transport and heating), the Government is committed to maximising indigenous resources, onshore and offshore, where it is cost-effective and in line with safety and environmental regulations to help ensure security of supply' (para 3.69). Similarly, government policy on shale gas and climate change effectively shares the Agency's approach here in being more concerned with what it calls 'local emissions' from shale gas operations and not calling into question emissions from shale gas's 'final use as a fuel' - see DECC ( $n$ 142).
} 
a neutral, technical framing, emptied of political weight) and, one assumes, also submissions on indirect off-site GHG emissions closely associated with the drilling process. Indirect, 'final use' global climate frames have not been acknowledged by and incorporated within the process however, because that calls into question government energy choices which are regarded as off-limits for the Agency.

\section{Conclusion}

Social movements and their opponents both vie to make their own particular interpretive frames of policy controversies the ones that are accepted in public consciousness and public policy. It is therefore not surprising to have seen such a framing contest in the context of fracking. On one side we have seen the anti-fracking movement emphasising 'negative' local environmental and global climate change frames, and on the other side there is the Government and oil and gas industry with their range of predominantly 'positive' economic and climate frames. Having explored these frames and counterframes, the current article proceeded to analyse the way in which planning and regulatory regimes controlling fracking have made space for some of the key frames to be considered within them. What is apparent from the study of the two regimes is that while both local environmental and global climate framing of fracking is acknowledged by them, the extent of the acceptance of the global climate frame remains limited. Although the regimes accept the relevance of information and argument concerning direct and some indirect climate emissions from fracking operations, the relevance of indirect 'final fuel use' emissions from the production stage appears to be at best unclear and, at worst, completely excluded insofar as this might be taken to call into question national government policy choices on energy. Because these ultimate policy choices are ones which must be considered as material or relevant considerations by MPAs and the Environment Agency, positive government framing of fracking inevitably wins through. Also interesting is the under-representation of the key pro-fracking, economic benefits frames in the new hydrocarbons planning practice guidance (though such frames remain in the generic minerals section of the National Planning Policy Framework, and are also inevitably represented in planning practice in planning applications themselves, with economic benefits such as local jobs creation having of course long been an important material consideration for planning authorities). While one would not expect such economic frames to be present within the Environment Agency's practice, they would be more expected within hydrocarbons planning guidance, and all the more so since the profracking Government makes such policy. ${ }^{157}$

In the end then, the current political opportunity structure, in the form of the planning and environmental permitting regimes, is rather resistant to one of the anti-fracking movement's key global climate frames involving fuel choices. It is probably too much to expect political agency on the part of the movement to alter the structural or procedural opportunity here (to get final fuel use included as a relevant consideration) in the way that Vanhala has suggested can happen with legal opportunity structure (ie that movements can help to shape such structure using agency and are not solely

\footnotetext{
${ }^{157}$ It may simply be that they wished to avoid duplication between the hydrocarbons planning guidance and the generic minerals policy in the National Planning Policy Framework. Even so, it remains surprising that the opportunity for frame reinforcement was not taken.
} 
determined by it). ${ }^{158}$ However, it may well be that such agency, in the shape of a repeated putting forward of the frame in both formal contexts (where it may continue to be excluded) and informal ones, could eventually help to achieve a substantive change in government policy on fracking in a similar way to how pressure from the anti-roads movement in the 1970s and 1980s arguably helped to change roads policy. ${ }^{159}$

In any event, such agency is likely to become much more critical if and when any of the existing exploratory operations reach the stage of making applications for planning permission and environmental permitting for commercial production. One might argue that, thus far, the relevant public authorities have not really been forced fully to confront the issue of GHGs in the final use of gas as a fuel because they have been able to kick the can further down the road by claiming that such questions are not appropriate for consideration at the exploration stage. However, when the production stage is reached, they become much more of a live issue that cannot be ducked in this way.

Acknowledgments

I am grateful to the referees and Editor for their helpful comments.

${ }^{158}$ Vanhala (n 33)

${ }^{159}$ Susan Owens, 'Siting, Sustainable Development and Social Priorities' (2004) 7 J of Risk Research 101, 106-107. 